Agro-Science Journal of Tropical Agriculture, Food, Environment and Extension Volume 20 Number 4 (Special Issue, October 2021) pp. 65 - 69

ISSN 1119-7455

\title{
MITIGATING COVID-19 EFFECTS ON FARMERS: THE ROLE OF COMMISSIONERS OF AGRICULTURE IN NIGERIA
}

\author{
${ }^{1}$ Idu M.A. and ${ }^{* 2}$ Onyenekwe C.S. \\ ${ }^{1}$ Department of Agricultural Economics, Michael Okpara University of Agriculture, Umudike, Nigeria \\ ${ }^{2}$ Department of Agricultural Economics, University of Nigeria, Nsukka, Nigeria \\ *Corresponding author email: chinasa.onyenekwe@unn.edu.ng
}

\begin{abstract}
In Nigeria, agriculture plays a critical role in the economy and remains the key to the country's economic diversification plan. However, the agricultural sector is facing numerous challenges such as climate change, widespread insecurity, price volatility, poor government policies and the emergence of COVID-19 pandemic has further exacerbated the already existing problems. This paper reviews the state of the COVID 19 pandemic in Nigeria and its effects on the agricultural sector and outlines the role of commissioners of agriculture in mitigating the effects of the pandemic on farmers with a view to catalyzing sustainable agricultural development in Nigeria. When the first case of COVID-19 was reported in February, 2020, the Federal government of Nigeria took some measures to help curb the spread of the virus. Although, these measures were critical to saving lives, they also significantly caused a disruption in agricultural activities and food systems in several ways such as decline in availability of farm labour and mechanization, limited availability of agricultural inputs, decline in food imports and exports, reduction in food supply, decline in household income and food consumption, increased food insecurity, panic buying and sharp price spikes. This paper suggests that commissioners of agriculture have important roles to play to help mitigate these negative impacts on agricultural livelihoods and food systems. These include a push for a bill to integrate social protection mechanisms into the Nigerian legal framework, lobby for increased budgetary allocation to the agricultural sector, formulation of good agricultural policies and provision of adequate infrastructures, organization of these farmers into farming clusters to help stimulate agglomeration economies by integrating agricultural value chains and development strategies, and frameworks and initiatives that will ensure a seamless transition from emergency response to resilience building.
\end{abstract}

Key words: Coronavirus disease, government interventions, agrarian development, food production

\section{INTRODUCTION}

In Nigeria, agriculture plays a critical role in the economy and has a significant role to play in sustainable development of the country. It is the largest employer of labour in the country, providing jobs for more than one-third (35\%) of the total work force (World Bank, 2020) and contributes about $24 \%$ to the Gross Domestic Product (GDP) (National Bureau of Statistics (NBS), 2020) The Nigerian agricultural sector remains the key to the country's economic diversification plan (PWC, 2020). Despite, the significance of the agricultural sector to the Nigerian economy it has been bedeviled by a number of challenges such as climate change, limited agricultural inputs, outdated systems of agriculture, poor infrastructure, lack of access to finance, absence of value chain and supply chain linkages, widespread insecurity including the Boko Haram crisis, armed banditry and cattle rustling in the North as well as incessant farmer-herder clashes in the South and Middle Belt (PWC, 2020). The emergence of COVID 19 pandemic has further exacerbated these already existing problems.
The presence of COVID-19 in Nigeria was first reported on $27^{\text {th }}$ February 2020 (Nigeria Centre for Disease Control, NCDC, 2020). As at $11^{\text {th }}$ October, 2021 the number of confirmed cases from the 36 states of the federation has risen to 207,709 (Nigeria Centre for Disease Control (NCDC), 2021). On $30^{\text {th }}$ March 2020 the Federal Government of Nigeria (FGN) and State Governments imposed a five-week lockdown across the 36 states including the Federal Capital Territory (FCT), Abuja, which was done in phases (FGN, 2020). The Government implemented further strict measures such as night curfew, ban on interstates and international travels, closure of domestic and international airports, closure of land borders, schools, suspension on all public gatherings such as religious gatherings, weddings, burials and parties as well as restrictions in the operation of food market outlet and open-air market. The lockdown was extended until $7^{\text {th }}$ August, 2020 when the Presidential Task Force on COVID-19 (PTF COVID-19) announced a gradual ease of the lockdown. These measures taken by FGN to manage the pandemic affected the agricultural sector and livelihoods in several ways. 
According to Andam et al. (2020) the agricultural sector suffered a $13.1 \%$ loss in output ( $\$ 1.2$ billion) and households lost on average $33 \%$ of their income. The measures restricted people's and labour mobility, reduced economic activity, impacted food systems, impacted livelihoods, disrupted transportation and logistics networks both locally and internationally and also caused some economies including the Nigerian economy to go into recession which could lead to the emergence of food and nutrition crisis.

According to FAO (2021a), an estimated 113 million people around the globe including Nigeria were already chronically food insecure even before the emergence of the COVID-19 due to the preexisting shocks. In Nigeria, prior to the outbreak of COVID 19, over 5 million people needed food assistance in 16 northern states, including the FCT, Abuja (PWC, 2020). Every year in Nigeria, farmer face risks such as low rainfall, price volatility, rising debts and poor government policies (Esiobu, 2020). But the present risks from the COVID-19 pandemic are putting new challenges in front of agricultural livelihoods that is already under serious threat. The number of persons in need of food assistance in North-East Nigeria has increased from 7.9 million in the beginning of 2020 to 10.6 million due to COVID- 19 and other factors, such as insurgency and armed banditry (Office for the Coordination of Humanitarian Affairs (OCHA), 2020).

These factors require both short-term and longterm responses from all stakeholders. The various arms of government architecture have critical roles to play in mitigating the negative impact of COVID 19 on agricultural livelihoods. Commissioners of agriculture by law are saddled with the responsibility of steering the development of agriculture in the country. They are responsible for a number of agricultural and environmental issues in each State such as food production and safety, forestry management, fishery management, pest control management, enforcing agricultural laws, etc. Therefore, this paper discusses some of the roles that these commissioners can play in mitigating the negative impact of COVID on agricultural livelihoods and systems. This is critical if the nation must achieve sustainable development.

As a background, however, the paper begins with assessing the effects of the COVID-19 pandemic on the agricultural livelihoods and systems Knowledge obtained in this regard would be crucial to expand the national capacity for enhanced preparation for dealing with the negative impact of COVID-19 pandemic on agricultural value chain in Nigeria. This is important if the nation will escape food crisis both at present and in the future and work towards the attainment of the SDGs of the UN especially SDG 2 which is aimed at ending hunger. The paper is divided into three sections. The first section highlights the negative impacts of COVID-19 on the agricultural sector, the second outlines the roles commissioners of agriculture can play in mitigating these negative impacts and the final section draws the conclusion.

\section{Effects of COVID-19 on Agriculture}

Like in many developing countries, the effect of COVID-19 on agriculture in Nigeria has been enormous due to the limited mechanization and high labour intensity in agriculture in the country. Over one-third (35\%) of the country's total labour force is employed in the agricultural sector (World Bank, 2020). Amankwah et al. (2021) reported that about $76 \%$ of households in Nigeria are involved in agriculture. The COVID-19 pandemic and the measures put in place by the Nigerian government to curb the spread of the disease affected farmers and agricultural workers in several ways. These measures while they were critical to saving lives also significantly caused a disruption in agricultural activities and value chain such as inputs supply into agriculture, production, distribution, transportation, marketing and consumption of agricultural products (Aromolaran et al., 2020; Oseni et al., 2020). It contributed to shortage of labour for agricultural production (Ilesanmi et al., 2021). Given the limited mechanization and high labour intensity in agriculture in Nigeria, there is usually high demand for labour during peaks of farming season, but the lockdown and restriction of movement limited access to farmlands by farmers and laborers (Nnodim, 2020). Consequently, there was a decrease in agricultural production throughout the country (Ilesanmi et al., 2021).

The effect of the pandemic on agriculture in Nigeria was very severe because the timing of the lockdown of the economy due to the outbreak coincided with the planting and harvesting seasons (March and July) of many crops such as maize, cucumber, tomatoes, millet, sorghum, rice, etc. Therefore, the shortage of hired labour for harvesting, resulted in high post-harvest losses by farmers, food shortages in the market and increased cost of food items (Nnodim, 2020). For instance, the price of a piece of egg increased from 42.78 in August 2020 to $\$ 55$ in October 2020 as a result of increase in the price of poultry feeds (Nnodim, 2020). Labour shortages has been blamed to have contributed to the reduction in the availability of maize for poultry feed formulation leading to a rise in price of maize from $\$ 0.23$ per $\mathrm{kg}$ in March 2020 to $\$ 0.47$ per $\mathrm{kg}$ in August 2020 (Berthout, 2020). It is because of this that the President, Muhammadu Buhari on the $3^{\text {rd }}$ of September, 2020 directed that 30,000 tonnes of maize from the national reserve be released to the poultry feed millers (Ojewale, 2020).

The pandemic also disrupted transportation of agricultural products and supply chains in different parts of the country due to the travel restrictions put in place. Although, the guidelines announced by the PTF Covid-19 allowed the movement of persons providing essential services such as health workers, movement of agricultural produce, petroleum products and some manufactured goods, movement restrictions were implemented by the security operatives indiscriminately and recklessly. Also, obtaining the necessary permit often proved difficult 
as offices were closed or had restricted working hours or limited personnel available to process requests (FAO, 2021b). This had some effects on small-scale farmers as many farmers' access to their farms and markets were restricted. Also, since, most small-scale farmers do not have storage facilities, they incurred a lot of post-harvest losses forcing some to sell their produce at very cheap prices (Small-Scale Women Farmers Organization in Nigeria, SWOFON, 2020). Even after the relaxation of the lockdown, security operatives kept harassing the farmers and where the farmers refuse to pay bribes, they stand the danger of having their produce destroyed and seized. This also discouraged many of the transporters from operating and the few who did ended up transferring the additional cost to farmers (SWOFON, 2020). These events resulted in increased wastage of perishable food items, low income to farmers and hike in prices of food items in the market.

The situation was further aggravated because the Nigerian government in August 2019, prior to the lockdown occasioned by COVID-19 had closed its land borders with neighboring Benin, Cameroun, Chad and Niger in order to stem the smuggling of goods particularly rice (Kassa and Zeufack, 2020). In addition, the closure of markets and borders affected inter and intra-country trade in agricultural inputs such as seeds, chemical fertilizers, and farm equipment and hindered farmers from selling there produce. The decline in trade in food and agricultural inputs affected the availability of food in most parts of the country and subsequent price spikes. Farm gate prices declined. So, farmers were making lower profits by selling in local markets while urban consumers were paying higher prices because of reduced supplies to the urban markets. Even with the relaxation of the lockdown, food prices have continued to increase (FAO, 2021b). For instance, a $50 \mathrm{~kg}$ bag of rice that use to be sold for $\$ 15,000$ earlier in the year 2020 increased to about $\$ 25,806$ by September 2020 (Nnodim, 2020). SWOFON (2020) reported that one bag of fertilizer which sold for $\$ 7,500$ in May, 2020 jumped to $\$ 17,000$ in August 2020.

Role of Commissioners of Agriculture in Mitigating the Effect of COVID-19 on Farmers Commissioners of agriculture can play the following roles to help cushion the effect of COVID-19 on farmers and agri-food systems:

- It is the role of governments both at the national and state levels to support farmers by providing palliatives such as free improved seedlings and other agro-inputs, basic farm implements and tractors at subsidized rates, free or cheaper extension services, cash- based intervention etc. to help cushion the negative impact of COVID 19. However, commissioners of agriculture can support this move by ensuring that palliatives are well distributed to the right persons. They should appoint personnel who have good track record for transparency, accountability and integrity to supervise these tasks to avoid situation where items or funds provided are diverted to private pockets. Commissioners of agriculture should collaborate with small scale farmer-based organizations in the disbursement for greater reach to smallholder farmer in remote rural areas.

Also, they should push for bill to integrate social protection mechanisms, like cash transfers, access to loans, credit-life insurance products and weather index insurance into the Nigerian legal framework. These social safety nets are important for agri-food enterprises, especially when there are temporary drops in their economic activity as a result of the COVID-19 pandemic. For instance, countries such as Malaysia, Dominican Republic, Thailand and South Africa have used unemployment protection scheme to support enterprises in retaining workers in employment as well as workers who have lost their jobs (ILO, 2020). In post COVID-19 pandemic era, such mechanisms can play a vital role in protecting agribusinesses and agricultural households especially in rural areas from crop failures, injecting finance into often cash-starved rural economies.

- Commissioners of agriculture in collaboration with civil organizations should continue to push and lobby for the budgetary allocation to the agriculture sector to be increased to the recommended $10 \%$ of the total budget as set by the Maputo Declaration on Agriculture and Food security to which Nigeria is a signatory to. The annual budgetary allocation to the sector has remained at abysmal level of below $2 \%$ for the past seven years (PWC, 2020). If this is achieved then more funds can be available and channeled to providing infrastructure to help boost agricultural production and support farmers so as to ensure that food production is sustained and food crisis averted.

- Commissioners of agriculture should help formulate good agricultural policies and provide adequate infrastructures such as good road networks, storage and processing plants, irrigation facilities, etc. Many smallholder farmers incur a lot of post-harvest losses and often are forced to sell their produce at low prices due to lack of storage facilities. Therefore, provision and maintenance of rural infrastructure will go a long way in minimizing post-harvest losses and enhancing product evacuation.

- About $80 \%$ of farmers in Nigeria are small holder farmers and produce about $90 \%$ of the country's agricultural output (Unah, 2018). Therefore, Commissioners of agriculture can help organize these farmers into farming clusters to help stimulate agglomeration economies by integrating agricultural value chains such as farmers, agro-input dealers, agro-processors, industrial manufacturers etc. The CBN's Anchor Borrowers Programme (ABP) is one attempt to 
bring back farming clusters in Nigeria. To ensure the efficiency of this farming clusters there must be adequate facilities (such as storage, processing, farm machineries, irrigation, distribution) provided at each cluster.

- To ensure a sustainable economic recovery post COVID-19 pandemic, commissioners of agriculture should promote mechanized farming by adopting smart technologies. Subsistence agriculture is not adequate to meet the challenges of the agricultural sector. To bring about agricultural transformation they should promote the use of technology and innovation to revamp agriculture as a pathway to speed up the post COVID-19 economic recovery.

- Commissioners of agriculture should ensure that there is free flow of agricultural inputs, such as seedlings, fertilizers as well as produce from the farm to markets by removing all logistical bottlenecks. They should also, provide guidance around actions for safe and resilient markets and food supply chains and short-term emergency responses.

- Commissioners of agriculture should support the federal government's effort to develop strategies, frameworks and initiatives that will ensure a seamless transition from emergency response to resilience building. They should support early recovery and resilience to shocks through asset creation and preservation, increased livelihood opportunities and enhance agricultural value chains.

- They should seek collaboration with international agencies and development partners for capacity building, secure funding and integrate technological innovations into the agricultural industry in the country.

\section{CONCLUSION}

COVID-19 and the response measure implemented by the FGN to curb the spread of the virus impacted agricultural livelihoods and agri-food systems in several ways such as decline in availability of farm labour and mechanization, limited availability of agricultural inputs, decline in food imports and exports, reduction in food availability, decline in household income and food consumption, increased food insecurity, panic buying and sharp price spikes etc. COVID-19 infections are still rising in Nigeria, and the federal, state, and local policies are evolving to respond to the disease and minimize the negative impacts. Policy makers will need insights from this paper to assess the impact of COVID-19 on the agricultural sector and ensure that adequate measures are put in place to mitigate these impacts. Such responses should be multi sectoral with effective coordination to ensure proper implementation and impact. It is important to take an agri-food systems approach that goes beyond primary agriculture to consider subsectors such as food processing, food trade and transport, and food services, which have strong linkages to the rest of the economy. Hence, agencies implementing policies aimed at supporting agriculture during the COVID-19 and the recovery period need to consider the broader agri-food system. Improving the resilience of agricultural systems through asset creation and preservation, increased livelihood opportunities and enhance agricultural value chains, will be one way of ensuring that future crisis have a more limited impact on farmers and agricultural livelihoods. In this way, commissioners of agriculture can support the recovery from COVID19 and build a more resilient Nigerian economy.

\section{REFERENCES}

Amankwah A., Gourlay S. and Zezza A. (2021). Agriculture as a buffer in COVID-19 crisis: Evidence from five Sub-Saharan African countries. Retrieved 08 Oct. 2021 from: https://blogs.worldbank.org/ opendata/agriculture-buffer-covid-19-crisisevidence-five-sub-saharan-african-countries

Andam K.S., Edeh H., Oboh V., Pauw K. and Thurlow J. (2020). Estimating the economic costs of COVID-19 in Nigeria. Nigeria Strategy Support Program (NSSP) Working Paper - (63) 19, p. 31. Retrieved from https:// doi.org/10.2499/p15738coll2.133846on 29/06/2021

Aromolaran A.B., Issa F.O. and Muyanga M. (2020). The unintended consequences of COVID-19 lockdown in Nigeria. Retrieved 30 Jun. 2021 from: https://www. future-agricultures.org/blog/the-unintended-conse quences-of-covid19-lockdown-in-nigeria/

Berthout N. (2020). Nigeria: Shortage of maize is crippling the poultry industry. Retrieved 30 Jun. 2021 from: https://www.poultryworld.net/Meat/Articles/ 2020 /8/Nigeria-Shortage-of-maize-is-crippling-thepoultry-industry-628784E/

Esiobu N. (2020). How does COVID-19 pandemic affect rice yield? Lessons from Southeast Nigeria. J. Biol. Agric. Healthcare, $10 \quad$ (15), 38-56. https://doi.org/10.7176/JBAH/10-15-06

FAO (2021a). The state of food security and nutrition in the world 2021. Food and Agriculture Organization (FAO), IFAD, UNICEF, WFP and WHO. https://doi.org/10.4060/CB4474EN

FAO (2021b). National agrifood systems and COVID-19 in Nigeria effects, policy responses and long-term implications. Rome. https://doi.org/10.4060/cb3631en

FGN (2020). Bouncing back: Nigeria economic sustainability plan. Federal Government of Nigeria (FGN) Retrieved 01 Jul. 2021 from: https://media. premiumtimesng.com/wp-content/files/2020/06/ ESC-Plan-compressed-1.pdf

Ilesanmi F. F., Ilesanmi O.S. and Afolabi A.A. (2021). The effects of the COVID-19 pandemic on food losses in the agricultural value chains in Africa: The Nigerian case study. Public Health in Practice, 2, 100087. https://doi.org/10.1016/j.puhip.2021.100087

ILO (2020). Social protection spotlights. Retrieved 12 Jul. 2021 from: https://www.ilo.org/wcmsp5/groups/ public/---ed_protect/---soc_sec/documents/publica tion/wcms_744612.pdf

Kassa W. and Z̄eufack A. (2020). Nigeria's border closure: A road block or a speed bump on the road to a successful AfCFTA? Retrieved 11 Oct. 2021 from: https://blogs. worldbank.org/africacan/nigerias-border-closureroad-block-or-speed-bump-road-successful-afcfta 
National Bureau of Statistics (NBS). (2020). Nigerian gross domestic product report. Retrieved 28 Jun. 2021 from: https://www.nigerianstat.gov.ng/pdfuploads/ GDP_Report_Q2_2020.pdf

Nigeria Centre for Disease Control (NCDC). (2020). First case of corona virus disease confirmed in Nigeria. Retrieved 29 Jun. 2021 from: https://ncdc.gov.ng/ news/227/first-case-of-corona-virus-diseaseconfirmed-in-nigeria

Nigeria Centre for Disease Control (NCDC). (2021). COVID-19 Nigeria. Retrieved 11 Oct. 2021 from: https://covid19.ncdc.gov.ng/

Nnodim O. (2020). Food production suffers, prices balloon as floods, COVID-19 devastate farmlands. Retrieved 08 Oct. 2021 from: https://www.msn. com/en-xl/news/other/food-production-suffersprices-balloon-as-floods-covid-19-devastatefarmlands/ar-BB1b2TSc

Office for the Coordination of Humanitarian Affairs (OCHA). (2020). Nigeria situation report, 26th November, 2020. Relief Web. Retrieved 11 Oct. 2021 from: https://reliefweb.int/report/nigeria/nigeria-situa tion-report-26-nov-2020

Ojewale C. (2020). Has Buhari emptied Nigeria's food reserves? Businessday NG. Retrieved 30 Jun. 2021 from: https://businessday.ng/agriculture/article/hasbuhari-emptied-nigerias-food-reserves/
Oseni G., Palacios-Lopez A., Mcgee K. and Amankwah A. (2020). Tracking the socioeconomic impacts of the pandemic in Nigeria: Results from the-19 national longitudinal phone survey. World Bank Blogs. Retrieved 30 Jun. 2021 from: https://blogs.worldbank. org/opendata/tracking-socioeconomic-impacts-pande mic-nigeria-results-first-three-rounds-nigeria-covid

PWC (2020). Responding to the impact of COVID-19 on food security and agriculture in Nigeria. Retrieved 28 Jun. 2021 from: https://www.pwc.com/ng/en/assets/ pdf/impact-covid19-food-security-nigeria.pdf

Small-Scale Women Farmers Organization in Nigeria, SWOFON (2020). The impact of COVID-19 on smallscale farmers in Nigeria. Heinrich Böll Stiftung. Retrieved 29 Jun. 2021 from: https://www.boell.de/ en/2020/ 08/04/impact-covid-19-small-scale-farmers-nigeria

Unah L. (2018). Agritech startups aim to lift Nigerian smallholder farmers out of poverty. Devex. Retrieved 01 Jul. 2021 from: https://www.devex.com/news/ agritech-startups-aim-to-lift-nigerian-smallholderfarmers-out-of-poverty-92646

World Bank. (2020). Employment in agriculture (\% of total employment) (modeled ILO estimate). Nigeria Data. Retrieved 28 Jun. 2021 from: https://data.world bank.org/indicator/SL.AGR.EMPL.ZS?locations=NG 